\title{
PENGARUH SALURAN DISTRIBUSI DAN IKLAN TERHADAP PENJUALAN PADA UKM BERKAH LAUT ERETAN KULON
}

\author{
The effect of distribution channels and advertising to sales
}

on UKM Berkah Laut Eretan Kulon

\author{
Surianti, Widia Wati \\ Manajemen FE Unwir \\ suriantife@unwir.ac.id
}

\begin{abstract}
ABSTRAK
Penelitian dilaksanakan pada UKM Berkah Laut Eretan Kulon, data diperoleh dari observasi, wawancara menggunakan kuisioner yang dibagikan kepada 79 orang pelanggan sebagai responden.

Saluran Distribusi pada UKM Berkah Laut termasuk dalam klasifikasi baik, karna terdapat : membuat prodak atau jasa yang siap digunakan, dan menyalurkan produk dalam status kepemilikan dari produsen ke konsumen, atribut bernilai lainnya yaitu $76 \%$ termasuk dalam klasifikasi "baik"

Iklan pada UKM Berkah Laut Eretan Kulon, termasuk dalam klasifikasi sangat baik, karna terdapat : komunikasi non personal yang dibiayai oleh sponsor, bagian dari bentuk promosi yang digunakan oleh perusahaan, dan media komunikasi dengan sejumlah biaya yang dilakukan oleh perusahaan, atribut bernilai lainnya yaitu $81 \%$ termasuk dalam klasifikasi "sangat baik"

Penjualan pada UKM Berkah Laut Eretan Kulon, termasuk dalam klasifikasi baik, karna terdapat : sumber pendapatan untuk menutup biaya, harapan untuk mendapatkan keuntungan dari kegiatan barang atau jasa yaitu sebesar $80 \%$ termasuk dalam kategori "baik".

Analisis korelasi antara saluran distribusi terhadap penjualan yaitu ryx1 $=0.433$ maka korelasi saluran distribusi terhadap penjualan termasuk dalam korelasi sedang. Antara iklan terhadap penjualan yaitu $\mathrm{ryx}^{2}=0.361$ maka korelasi antara iklan terhadap penjualan tergolong dalam korelasi sedang. Antara saluran distribusi dan iklan secara simultan terhadap penjualan yaitu, ryx1x2 $=0.544$ maka korelasi saluran distribusi dan iklan terhadap penjualan tergolong dalam korelasi sedang.
\end{abstract}

Uji hipotesis antara saluran distribusi terhadap penjualan diperoleh $\mathrm{t}$ hitung $=\mathbf{4 . 2 1 3}$ sedangkan $T$ tabel dengan taraf signifikasi 5\% adalah 1.991 Karna t hitung lebih besar dari Ttabel 4.213 > 1.991 maka Ho ditolak dan Ha diterima, artinya terdapat pengaruh antara saluran distribusi terhadap penjualan. Antara iklan terhadap penjualan diperoleh $\mathrm{t}$ hitung $=\mathbf{3 . 3 9 5}$ sedangkan $\mathrm{T}$ tabel dengan taraf signifikasi $5 \%$ adalah 1.991 Karna $T$ hitung lebih besar dari $T$ tabel $3.395>1.991$ maka Ho ditolak dan Ha diterima, artinya ada pengaruh antara iklan terhadap penjualan. Antara saluran distribusi dan iklan secara simultan terhadap penjualan diperoleh $\mathrm{t}$ hitung $=\mathbf{5 . 6 8 4}$ sedangkan Ttabel dengan taraf signifikasi 5\% adalah 1.991 Karna Thitung lebih besar dari Ttabel 5.684 > 1.991 maka Ho ditolak dan Ha diterima. Artinya ada pengaruh antara saluran distribusi dan iklan terhadap penjualan.

Kata Kunci: Saluran Distribusi, Iklan, Penjualan.

\section{ABSTRACT}

The experiment was conducted at UKM Berkah Laut Eretan Kulon, data obtained from observation, interview using questionnaire distributed to 79 customers as respondents.

Distribution channels at UKM Berkah Laut Eretan Kulon included in both classifications, because there are: make product or services that are ready for use, and distribute the product in the ownership status of the producer to the consumer, other valuable attributes which $76 \%$ were categorized as "good"

The advertisement at UKM Berkah Laut Eretan Kulon, belongs to a very good classification, because there are: non-personal communications funded by the sponsor, part of the promotional form used by the company, and the communication medium with a certain amount of costs made by the company, another valuable attribute that is $81 \%$ were categorized as "very good"

Sales at UKM Berkah Laut Eretan Kulon, are included in the good classification, because there are: sources of income to cover costs, the expectation to profit from goods or services activities that is $80 \%$ included in the "good" category.

Correlation analysis between the sale of customer satisfaction is the correlation ryx $1=0.433$ then the correlation distribution channel to sales is included in the correlation being. Between advertising on sales is ryx $2=0.361$ then the 
correlation between advertising to sales classified in moderate correlation. Between distribution and advertising channels simultaneously on sales that is, ryx 1 x $2=0544$ the correlation distribution channels and advertising to sales classified in moderate correlation.

Hypothesis test between distribution channel to sales obtained $t$ count $=\mathbf{4 . 2 1 3}$ while $\mathrm{T}$ table with $5 \%$ significance level is 1.991 Because $t$ count bigger than $T$ table 4.213> 1.991 then Ho rejected and $\mathrm{Ha}$ accepted, meaning there is influence between distribution channel to sales. Between advertising to the sale obtained $t$ count $=\mathbf{3 . 3 9 5}$ while $\mathrm{T}$ table with $5 \%$ significance level is $\mathbf{1 , 9 9 1}$ Because $T$ count greater than $T$ table 3.395> 1.991 then Ho is rejected and Ha accepted, meaning there is influence between ads on sales. Between distribution channel and advertisement simultaneously to sales obtained $t$ count $=\mathbf{5 . 6 8 4}$ while $\mathrm{T}$ table with $\mathbf{5 \%}$ significance level is $\mathbf{1 . 9 9 1}$ Because $T$ count greater than $T$ table 5.684> 1.991 then $\mathrm{Ho}$ is rejected and $\mathrm{Ha}$ accepted. Meaning there is an influence between distribution channels and advertising on sales.

Keywords: Distribution Channels, Advertising, Sales.

\section{PENDAHULUAN}

Tujuan perusahaan dalam aktivitas kegiatannya adalah pencapaian target penjualan sesuai yang direncanakan dan mendapatkan suatu keuntungan atau laba. Penjualan adalah suatu sistem kegiatan pokok perusahaan untuk memperjual belikan barang dan jasa yang dihasilkan oleh perusahaan. Kegiatan penjualan merupakan bagian dari kegiatan pemasaran, dimana keberhasilan pemasaran akan ditentukan oleh berbagai faktor yang mempengaruhinya. Adapun faktor-faktor yang dimaksud berupa faktor internal yaitu faktor yang dapat dikendalikan oleh perusahaan yang terdiri dari beberapa variabel seperti produk, promosi, harga dan distribusi yang sering disebut dengan istilah marketing mix.
Sedangkan faktor yang lain berupa faktor eksternal yaitu faktor yang tidak dapat dikendalikan oleh perusahaan yang terdiri dari lingkungan mikro dan makro. Lingkungan mikro terdiri dari beberapa variabel seperti pemasok, perantara pemasaran, pelanggan, pesaing, perusahaan distribusi fisik dan publik. Sedangkan Lingkungan makro terdiri dari beberapa variabel seperti Demografi dan Geografi.

UKM Berkah Laut dihadapkan pada suatu kondisi persaingan yang ketat, dimana bermunculan UKM sejenis yang menawarkan produk-produk baru. Untuk dapat mendukung keberhasilan pemasaran yang pada akhirnya Akan berdampak terhadap keberhasilan kegiatan penjualan, maka hal ini akan tergantung pada kemampuan manajemen dalam menganalisis dan memanfaatkan berbagai variabel yang dimilikinya serta merancang secara strategis program-program pemasaran dalam kerangka lingkungan yang dihadapi perusahaan dan menjalankan rencana tersebut.

Saluran Distribusi merupakan salah satu variabel dari beberapa variabel pemasaran lainnya sehingga sangat penting untuk diperhatikan oleh setiap perusahaan. Saluran Distribusi adalah organisasi-organisasi yang saling tergantung yang tercakup dalam proses yang membuat produk atau jasa menjadi tersedia untuk digunakan atau dikonsumsi. Penentuan saluran distribusi 
sebagai salah satu unsur dari pada bauran distribusi dianggap sebagai salah satu kegiatan kritis yang dihadapi manajemen karena dapat mempengaruhi seluruh keputusan-keputusan pemasaran lainnya, seperti keputusan mengenai produk, harga, promosi, dan lain-lainnya. Disamping itu pemilihan saluran distribusi akan menyangkut keputusan-keputusan mengenai penggunaan penyalur atau perantara pemasaran seperti grosir, agen, makelar, pengecer dan jenis penyalur lainnya serta bagaimana untuk menjalin hubungan yang baik dan saling menguntungkan dengan para perantara atau penyalur tersebut dalam jangka waktu yang panjang.

Penginformasian suatu barang atau jasa perusahaan menggunakan cara dengan penggunaan peningkatan bauran promosinya. Dalam pelaksanaan bauran promosi seperti periklanan, penjualan pribadi, sales promotion, publicity maupun penjualan langsung dilakukan untuk meningkatkan penjualannya. Dalam hal ini perusahaan beranggapan salah satu alat yang digunakan dalam penginformasian barang ini adalah bagaimana penggunaan periklanan. Sehingga apa yang menjadi tujuan dari periklanan seperti menginformasikan, mengingatkan, membujuk, dan mempengaruhi konsumen baik secara langsung maupun tidak langsung sehingga konsumen tertarik untuk membelinya dan hal ini akan berdampak pada peningkatan penjualan.

\section{TINJAUAN PUSTAKA}

Penjualan menurut Basu Swastha DH dan Ibnu Sukotjo (2010:183) menyatakan bahwa "Penjualan adalah sumber pendapatan yang diperlukan untuk menutup biaya-biaya dengan harapan bisa mendapatkan keuntungan atau laba".

Sedangkan Menurut Mulyadi (2013:202) menyatakan bahwa "Penjualan adalah kegiatan pengalihan barang atau jasa dengan harapan akan memperoleh laba dari adanya transaksi-transaksi tersebut dan penjualan dapat diartikan sebagai pengalihan atau pemindahan hak kepemilikan atas barang atau jasa dari pihak penjual dan pembeli".

Menurut Henry Simamora (2012: 24), menyatakan bahwa "Penjualan adalah pendapatan lazim dalam perusahaan dan merupakan jumlah kotor yang dibebankan kepada pelanggan atas barang dan jasa".

Dari beberapa definisi para ahli diatas, peneliti berkesimpulan bahwa penjualan adalah Sumber pendapatan untuk menutup biaya dengan harapan mendapatkan keuntungan atau laba dari kegiatan pengalihan atau pemindahan hak kepemilikan barang atau jasa dengan membebankan biaya kepada pelanggan.

Menurut Basu Swastha Dh (2012: 129) dalam praktek, kegiatan penjualan itu dipengaruhi oleh beberapa faktor, faktorfaktor tersebut adalah:

1. Kondisi dan Kemampuan Penjual 
Transaksi jual-beli atau pemindahan hak milik secara komersial atas barang dan jasa itu pada prinsipnya melibatkan dua pihak, yaitu penjual sebagai pihak pertama dan pembeli sebagai pihak kedua. Di sini, penjual harus dapat meyakinkan kepada pembelinya agar dapat berhasil mencapai sasaran penjualan yang diharapkan. Untuk maksud tersebut penjual harus memahami beberapa masalah penting yang sangat berkaitan, yakni:

a. Jenis dan karakteristik barang yang ditawarkan.

b. Harga produk.

c. Syarat penjualan, seperti: pembayaran, penghantaran, pelayanan purna jual, garansi dan sebagainya.

\section{Kondisi Pasar}

Pasar, sebagai kelompok pembeli atau pihak yang menjadi sasaran dalam penjualan, dapat pula mempengaruhi kegiatan penjualannya. Adapun faktor-faktor kondisi pasar yang perlu diperhatikan adalah:

a. Jenis pasarnya, apakah pasar konsumen, pasar industri, pasar penjual, pasar pemerintah ataukah pasar internasional.

b. Kelompok pembeli atau segmen pasarnya.

c. Daya belinya.

d. Frekuensi pembelinya.

e. Keinginan dan kebutuhannya.

\section{Modal}

Akan lebih sulit bagi penjual untuk menjual barangnya apakah barang yang dijual tersebut belum dikenal oleh calon pembeli atau apabila lokasi pembeli jauh dari tempat penjual. Dalam keadaan seperti ini, penjual harus memperkenalkan dulu atau membawa barangnya ke tempat pembeli. Untuk melaksanakan maksud tersebut diperlukan adanya sarana serta usaha, seperti: alat transport, tempat peragaan baik di dalam perusahaan maupun di luar perusahaan, usaha promosi dan sebagainya. Semua ini hanya dapat dilakukan apabila penjual memiliki sejumlah modal yang diperlukan untuk itu.

\section{Kondisi Organisasi Perusahaan}

Pada perusahaan besar, biasanya masalah penjualan ini ditangani oleh bagian tersendiri (Bagian Penjualan) yang dipegang orang-orang tertentu/ahli dibidang penjualan. Lain halnya dengan perusahaan kecil di mana masalah penjualan ditangani oleh orang yang juga melakukan fungsi-fungsi lain.

\section{Faktor Lain}

Faktor-faktor lain, seperti: periklanan, peragaan, kampanye, pemberian hadiah, sering mempengaruhi penjualan. Namun untuk melaksanakannya, diperlukan sejumlah dana yang tidak sedikit. Bagi perusahaan yang bermodal kuat, kegiatan ini secara rutin dapat dilakukan. Sedangkan bagi perusahaan kecil yang mempunyai modal relative kecil, kegiatan ini lebih jarang dilakukan. Ada pengusaha yang berpegang pada suatu prinsip bahwa "paling penting membuat barang yang baik". Bilamana prinsip tersebut dilaksanakan, maka 
diharapkan pembeli akan kembali membeli lagi barang yang sama. Namun, sebelum pembelian dilakukan, sering pembeli harus dirangsang daya tariknya, misalnya dengan memberikan bungkus yang menarik atau dengan cara promosi lainnya.

Dalam penjualan barang ini tentunya diperlukan saluran distribusi. Menurut Philip Kotler Dan Gary Amstrong (2012 : 62 ) menyatakan bahwa "Saluran Distribusi adalah sekumpulan organisasi yang saling bergantung yang terlibat dalam proses yang membuat produk atau jasa yang siap digunakan atau dikonsumsi oleh konsumen atau pengguna bisnis".

Sementara menurut Stanton, Etzel dan Wal ker (1994) dikutip dari buku Danang Sunyoto (2015:180), bahwa "Saluran Distribusi adalah terdiri dari serangkaian lembaga yang melakukan semua kegiatan yang digunakan untuk menyalurkan produk dan status pemilikannya dari produsen ke konsumen akhir atau pemakai bisnis".

Dan menurut Basu Swasta DH dan Ibnu Sukotjo (2010:200) menyatakan bahwa "Saluran distribusi adalah saluran yang digunakan oleh produsen untuk menyalurkan barang tersebut dari produsen sampai ke konsumen atau pemakai industri”.

Dari beberapa pendapat para ahli diatas, saluran distribusi adalah Sekumpulan organisasi yang saling bergantung dalam proses membuat prodak atau jasa yang siap digunakan atau dikonsumsi dan menyalurkan produk dan status kepemilikan dari produsen ke konsumen akhir atau pemakai bisnis. Menurut Fandy Tjiptono (2008:189) faktorfaktor yang mempengaruhi distribusi antara lain :

1.Pertimbangan pasar

a. jenis pasar

misalnya untuk mencapai pasar industri perusahaan tidak akan memerlukan pengecer.

b.jumlah pelanggan potensial

jika pelanggan potensial relatif sedikit, maka lebih baik bila perusahaan memakai tenaga penjual sendiri untuk menjual secara langsung kepada pembeli individual dan pembeli industrial. Sebaliknya perusahaan lebih baik menggunakan perantara jika pelanggan potensial relatif banyak.

c. Konsentrasi geografis pasar

Pemasar cenderung mendirikan cabangcabang penjualan di pasar yang berpenduduk padat dan menggunakan perantara untuk pasar yang berpenduduk jarang.

d.Jumlah dan ukuran pemesanan

Sebuah perusahaan manufaktur akan menjual secara langsung pada jaringan grosir yang besar, karena jumlah pemesanan yang besar menyebabkan bentuk pemesanan langsung ini lebih banyak (feasible). Sedangkan untuk pedagang grosir kecil yang peranannya relatif kecil, perusahaan akan menggunakan pedagang grosir (wholesaler) untuk melakukan penjualan langsung.

2.Pertimbangan produk 
a. Nilai unit (unit value)

Semakin rendah nilai unit maka saluran distribusinya semakin panjang. Namun jika produk nilai unitnya rendah itu dijual dalam kuantitas besar atau dikombinasikan dengan barang-barang lain sehingga jumlah pesanan total menjadi besar, maka saluran distribusi yang pendek secara ekonomis lebih feasible. b.Perishability

Untuk produk-produk yang fisiknya mudah rusak dan tidak tahan lama lebih baik disalurkan melalui saluran distribusi pendek. Hal ini dimaksudkan agar produk sampai ke tangan konsumen dengan kondisi yang baik. c. Sifat teknis produk

Produk-produk industri yang bersifat sangat teknis seringkali harus didistribusikan secara langsung karena armada penjualan produsen akan lebih dapat memberikan pelayanan yang diperlukan ( baik sebelum maupun sesudah pembelian ) dan lebih menguasai segala aspek yang berkaitan dengan barang tersebut.

3. Pertimbangan tentang perantara

a. Jasa yang diberikan perantara

Produsen hendaknya memilih perantara yang memberi jasa pemasaran yang tidak bisa dilakukan perusahaan secara teknis maupun ekonomis.

b. Keberadaan perantara yang diinginkan

Kesulitan yang dihadapi adalah bahwa seringkali yang diinginkan produsen tersebut juga menyalurkan produk-produk yang bersaing dan mereka tidak bersedia menambah lini produknya.

c. Sikap perantara terhadap kebijakan perusahaan

Kadang-kadang pemilihan distribusi produsen menjadi terbatas karena kebijakan pemasarannya tidak bisa diterima oleh perantara-perantara tertentu.

4.Pertimbangan perusahaan

a. Sumber-sumber finansial

Perusahaan yang kuat keuangannya cenderung lebih tertarik untuk mengorganisasikan armada penjualnya sendiri sehingga mereka relatif kurang menggunakan perantara.

b. Kemampuan manajemen

Pemilihan saluran juga dapat dipengaruhi oleh pengalaman dan kemampuan pemasaran dari pihak manajemen perusahaan. Kurangnya pengalaman dan kemampuan perusahaan akan menyebabkan perusahaan lebih suka memanfaatkan perantara untuk mendistribusikan barangnya.

c. Tingkat pengendalian yang diinginkan

Apabila dapat mengendalikan saluran distribusi, maka perusahaan dapat melakukan promosi yang agresif dan dapat mengawasi kondisi persediaan barang dan harga eceran produknya.

d.Jasa yang diberikan penjual

Seringkali perusahaan harus memberikan jasa-jasa pemasaran karena permintaan dari perantara. 


\section{e. Lingkungan}

Pada situasi ekonomi yang lesu, produsen cenderung menyalurkan barangnya ke pasar dengan cara yang paling ekonomis, yaitu menggunakan saluran distribusi pendek.

Menurut Ralph S. Alexander dalam Morissan (2010:17) menyatakan bahwa "Iklan adalah setiap bentuk komunikasi nonpersonal mengenai suatu organisasi, produk, servis, atau ide yang dibayar oleh satu sponsor yang diketahui”.

Menurut Tjiptono (2008: 225) menyatakan bahwa "Iklan merupakan salah satu bentuk promosi yang paling banyak digunakan perusahaan dalam mempromosikan produknya".

Menurut Basu Swasta DH dan Ibnu Sukotjo (2010:222) menyatakan bahwa "Iklan adalah komunikasi non-individu, dengan sejumlah biaya, melalui berbagai media yang dilakukan oleh perusahaan, lembaga non-laba, serta individu".

Dari beberapa definisi para ahli diatas, peneliti merangkum bahwa iklan adalah bentuk komunikasi nonpersonal yang dibiayai oleh sponsor dan bagian dari bentuk promosi yang digunakan perusahaan melalui berbagai media komunikasi dengan sejumlah biaya yang dilakukan oleh perusahaan

\section{METODOLOGI PENELITIAN}

Metode dapat diartikan sebagai suatu cara untuk mencari, memperoleh, mengumpulkan atau mencatat data baik berupa data primer maupun data sekunder yang digunakan untuk keperluan menyusun suatu karya ilmiah dan kemudian dianalisa sehingga akan terdapat suatu kebenaran dari data yang diperoleh.

Menurut Sugiyono (2013:1), "metode penelitian pada dasarnya merupakan cara ilmiah untuk mendapatkan data dengan tujuan dan kegunaan tertentu. Berdasarkan hal tersebut terdapat empat kata kunci yang perlu diperhatikan yaitu cara ilmiah, data, tujuan dan kegunaan."

Metode penelitian yang digunakan dalam penelitian ini adalah metode deskriptif dan asosiatif, yaitu suatu metode penelitian yang memberikan gambaran dan mengungkapkan suatu masalah yang terjadi pada saat penelitian berlangsung dengan mengumpulkan data dari UKM Berkah Laut Eretan Kulon Kandanghaur Indramayu yang kemudian disusun, sehingga dapat dibuat kesimpulan dan saran dengan tujuan untuk memberikan deskripsi yang sistematis dan akurat mengenai objek yang diteliti.

Menurut Sugiyono (2013:29) menjelaskan bahwa,"metode deskriptif adalah "penelitian yang dimaksudkan untuk menyelidiki keadaan, kondisi atau hal-hal lain yang sudah disebutkan, yang hasilnya dipaparkan dalam bentuk laporan penelitian". Penelitian deskriptif disini bertujuan untuk memperoleh gambaran mengenai saluran distribusi dan iklan pada UKM Berkah Laut Eretan Kulon Kandanghaur Indramayu. 
Sedangkan metode asosiatif menurut Sugiyono (2013: 89) bahwa, "metode asosiatif adalah suatu pernyataan yang menunjukan dugaan tentang hubungan antara dua variabel atau lebih". Dalam penelitian ini Akan diuji mengenai kebenaran hipotesis melalui pengumpulan data di lapangan apakah terdapat pengaruh saluran distribusi dan iklan terhadap penjualan pada UKM Berkah Laut Eretan Kulon Kandanghaur Indramayu.

\section{Kerangka Pemikiran}

Rancangan penelitian dalam penelitian ini sebagai berikut :

\section{Gambar.1}

\section{Desain Kerangka Pemikiran}

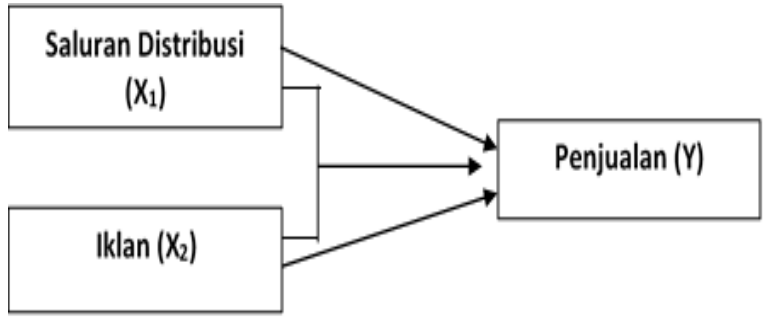

Dari kerangka pemikiran tersebut, terdapat tiga variabel yang akan diteliti yaitu Saluran distribusi $\left(\mathrm{X}_{1}\right)$, Iklan $\left(\mathrm{X}_{2}\right)$ dan Penjualan (Y). Kerangka pemikiran tersebut dinyatakan dengan variabel Simultan, berikut desain penelitiannya.

Hipotesis merupakan jawaban sementara terhadap masalah penelitian yang kebenarannya masih harus diuji secara empiris.

Menurut Sugiyono (2013:84) “Hipotesis diartikan sebagai jawaban sementara terhadap rumusan masalah penelitian”. Dari pendapat tersebut maka suatu hipotesis yang dikemukakan nantinya bukanlah suatu jawaban yang benar secara mutlak, tetapi dipakai sebagai jalan untuk mengatasi permasalahan yang ada dan masih harus dibuktikan kebenarannya.

Berdasarkan uraian kerangka pemikiran, maka secara hipotesis statistik dinyatakan sebagai berikut :

1. $\mathrm{H}_{1}=\mathrm{Ho} ; \mathrm{r}=0$ Diduga tidak ada pengaruh antara saluran distribusi terhadap penjualan

2. $\mathrm{H}_{1}=\mathrm{Ha} ; \mathrm{r} \neq 0$ Diduga terdapat pengaruh antara saluran distribusi terhadap penjualan

3. $\mathrm{H}_{2}=\mathrm{Ho} ; \mathrm{r}=0$ Diduga tidak ada pengaruh antara iklan terhadap penjualan

4. $\mathrm{H}_{2}=\mathrm{Ha} ; \mathrm{r} \neq 0$ Diduga terdapat pengaruh antara iklan terhadap penjualan

5. $\mathrm{H}_{3}=\mathrm{Ho} ; \mathrm{r}=0$ Diduga tidak ada pengaruh antara saluran distribusi dan iklan terhadap penjualan

6. $\mathrm{H}_{3}=\mathrm{Ha} ; \mathrm{r} \neq 0$ Diduga terdapat pengaruh antara saluran distribusi dan iklan terhadap penjualan

Berdasarkan tujuan dilakukannya penelitian ini, maka yang akan di analisis adalah variabel Independen yaitu saluran distribusi (variabel $\mathrm{X}_{1}$ ) dan Iklan (variabel $\mathrm{X}_{2}$ ) sedangkan variabel dependen adalah penjualan (Y). Dengan memperhatikan karakteristik yang akan diuji, maka uji statistik yang digunakan adalah melalui perhitungan analisis linier regresi ganda 
untuk ketiga variabel tersebut. Adapun yang menjadi hipotesis dalam penelitian ini adalah terdapat pengaruh yang positif antara Saluran Distribusi dan Iklan terhadap Penjualan produk makanan ringan UKM Berkah Laut Eretan Kulon Kandanghaur Indramayu.

\section{PEMBAHASAN}

\section{Analisis Korelasi}

Untuk menganalisis atau mencari koefisien korelasi menggunakan rumus sebagai berikut:

$$
r y x_{1}=\frac{n(\Sigma x y)-(\Sigma x)\left(\sum y\right)}{\sqrt{\left[n\left(\Sigma x^{2}\right)-(\Sigma x)^{2}\right]\left[n\left(\Sigma y^{2}\right)-(\Sigma y)^{2}\right]}}
$$

a. Koefisien Korelasi Antara Saluran

\section{Distribusi Terhadap Penjualan}

$$
\begin{gathered}
r y x_{1}=\frac{79(45444)-(\Sigma 1878)(1905)}{\sqrt{\left[79(\Sigma 45088)-(\Sigma 1878)^{2}\right]\left[79(\Sigma 46237)-(\Sigma 1905)^{2}\right]}} \\
r y x_{1}=\frac{3590076-3577590}{\sqrt{[3561952-3526884][3652723-3629025]}} \\
r y x_{1}=\frac{12486}{\sqrt{831041464}} \\
r y x_{1}=\frac{12486}{28827.78} \\
r y x_{1}=0.433
\end{gathered}
$$

Dengan diperolehnya nilai $r y x_{l}=0.433$ maka korelasi saluran distribusi terhadap penjualan termasuk dalam korelasi sedang.

\section{b. Koefisien Korelasi Antara Iklan}

\section{Terhadap Penjualan}

$$
\begin{gathered}
r y x_{2}=\frac{79\left(\sum 46275\right)-(\Sigma 1914)(1905)}{\sqrt{\left[79\left(\sum 46746\right)-(\Sigma 1914)^{2}\right]\left[79(\Sigma 46237)-(\Sigma 1905)^{2}\right]}} \\
r y x_{2}=\frac{3655725-3646170}{\sqrt{[3692934-3663396][3652723-3629025]}} \\
r y x_{2}=\frac{9555}{\sqrt{699991524}} \\
r y x_{2}=\frac{9555}{26457.35}
\end{gathered}
$$

$$
r y x_{2}=0.361
$$

Dengan diperolehnya nilai $r y x_{2}=0.361$ maka korelasi iklan terhadap penjualan tergolong dalam korelasi sedang.

\section{c. Koefisien Korelasi Antara Saluran Distribusi dan Iklan}

$$
\begin{gathered}
r x_{1} x_{2}=\frac{79(45529)-(1878)(1914)}{\sqrt{\left[79(45088)-(1878)^{2}\right]\left[79(46746)-(1914)^{2}\right]}} \\
r x_{1} x_{2}=\frac{3596791-3594492}{\sqrt{[3561952-3526884][3692934-3663396]}} \\
r x_{1} x_{2}=\frac{2299}{\sqrt{1035838584}} \\
r x_{1} x_{2}=\frac{2299}{32184.44} \\
r_{1} x_{2}=0.071
\end{gathered}
$$

Dengan diperolehnya nilai $r x_{1} x_{2}=0.071$ maka korelasi Saluran Distribusi dengan Iklan termasuk dalam korelasi rendah.

\section{d. Koefisien Korelasi Antara Saluran Distribusi dan Iklan Secara Simultan Terhadap Penjualan.}

Koefisien korelasi berganda antara Saluran Distribusi dan Iklan Secara Simultan Terhadap Penjualan. dapat dihitung dengan menggunaka rumus sebagai berikut]̣]: $r y x_{1} x_{2} \sqrt{\left.\left.\frac{\left.\left\{(r y x)^{2}\right)+\left(r y x_{2}\right)^{2}\right)-(2)(r y x)\left(r y x_{2}\right)(r x}{x_{2}}\right)\right\}}$

Dimana :

$$
\begin{aligned}
& r y x_{1}=0.433 \\
& r y x_{2}=0.361 \\
& r x_{1} x_{2}=0.071
\end{aligned}
$$

Maka dapat dihitung melalui rumus diatas : 
Riri Nur Fajriah, Fitria Damayanti

$$
\begin{gathered}
r y x_{1} x_{2}=\sqrt{\frac{\left.\left.\left\{(0.433)^{2}\right)+(0.361)^{2}\right)-(2)(0.433)(0.361)(0.071)\right\}}{\left\{1-(0.071)^{2}\right\}}} \\
\text { ryx }_{1} x_{2}=\sqrt{\frac{0.317-0.022}{1-(0.071)^{2}}} \\
\operatorname{ryx}_{1} x_{2}=\sqrt{\frac{0.295}{0.994}} \\
\operatorname{ryx}_{1} x_{2}=\sqrt{0.296} \\
\operatorname{ryx}_{1} x_{2}=0.544
\end{gathered}
$$

Diperolehnya nilai $r y x_{1} x_{2}=0.544$

artinya hubungan antara Saluran Distribusi dan Iklan Terhadap Penjualan termasuk dalam korelasi sedang.

\section{Koefisien Determinasi (KD)}

Unttuk mengetahui seberapa besar kontribusi yang diberikan variabel terikat terhadap variabel bebas dengan menggunakan Koefisien Determinasi.

Berdasarkan perhitungan dan data yang diperoleh untuk mengetahui presentase pengaruh saluran distribusi dan iklan terhadap penjualan, analisis koefisien determinan dengan nilai:

$$
\begin{aligned}
& \operatorname{ryx}_{1}=0.433 \\
& \operatorname{ryx}_{2}=0.361 \\
& \operatorname{ryx}_{1} x_{2}=0.544
\end{aligned}
$$

Sehingga koefisien determinasi dapat diketahui dengan menggunakan persamaan: $\mathrm{KD}=\mathrm{r}^{2} \times 100 \%$

\section{a. Koefisien Determinasi (KD) Saluran Distribusi terhadap Penjualan}

Untuk mengetahui seberapa besar konstribusi yang diberikan saluran distribusi terhadap penjualan maka dapat disimpulkan dengan koefisien determinasi sebagai berikut:

$$
\begin{aligned}
& K D=r^{2} \times 100 \% \\
& K D=0.433^{2} \times 100 \%
\end{aligned}
$$

$$
\mathrm{KD}=19 \%
$$

Dengan nilai KD $=19 \%$ berarti konstribusi saluran distribusi terhadap penjualan adalah sebesar $19 \%$ dan sisanya sebesar $81 \%$ berasal dari faktor lain yang tidak diteliti.

\section{b. Koefisien Determinasi (KD) Iklan terhadap Penjualan}

Untuk mengetahui seberapa besar konstribusi yang diberikan iklan terhadap penjualan maka dapat disimpulkan dengan koefisien determinasi sebagai berikut:

$$
\begin{aligned}
& K D=r^{2} \times 100 \% \\
& K D=0.361^{2} \times 100 \% \\
& K D=13 \%
\end{aligned}
$$

Dengan nilai $K D=13 \%$ berarti konstribusi iklan terhadap penjualan adalah sebesar $13 \%$ dan sisanya sebesar $77 \%$ berasal dari faktor lain yang tidak diteliti. 
c. Koefisien Determinasi (KD) Saluran

Distribusi Dan Iklan Secara Simultan

Terhadap Penjualan

Untuk mengetahui seberapa besar konstribusi yang diberikan saluran distribusi dan iklan terhadap penjualan maka dapat disimpulkan dengan koefisien determinasi sebagai berikut:

$$
\begin{aligned}
& K D=r^{2} \times 100 \% \\
& K D=0.544^{2} \times 100 \% \\
& K D=30 \%
\end{aligned}
$$

Dengan nilai $\mathrm{KD}=30 \%$ berarti konstribusi saluran distribusi dan iklan terhadap penjualan adalah sebesar $30 \%$ dan sisanya sebesar $70 \%$ berasal dari faktor lain yang tidak diteliti.

\section{Pengujian Hipotesis}

Pengujian hipotesis dimaksudkan sebagai cara untuk menentukan suatu hipotesis apakah suatu hipotesa tersebut diterima atau ditolak.

Rumus uji hipotesis adalah sebagai berikut: $t=r \sqrt{\frac{n-2}{1-r^{2}}}$

a. Uji Hipotesis Pengaruh Saluran Distribusi terhadap Penjualan

$$
\begin{aligned}
& t=0.433 \sqrt{\frac{79-2}{1-(0.433)^{2}}} \\
& t=0.433 \sqrt{\frac{77}{1-0.187}}
\end{aligned}
$$

$$
\begin{aligned}
& t=0.433 \sqrt{\frac{77}{0.813}} \\
& t=0.433(9.731) \\
& t=4.213
\end{aligned}
$$

Berdasarkan hasil perhitungan diatas diperoleh t.hitung $=4.213$ sedangkan t.tabel dengan taraf signifikasi $5 \%$ dan derajat kebebasan $\mathrm{Dk}=\mathrm{n}-2$ atau $79-2=77$, maka $a$ $=1.991$, Karna t.hitung lebih besar dari t.tabel yaitu $4.213>1,991$ maka Ho ditolak dan Ha diterima, artinya terdapat pengaruh antara Saluran Distribusi terhadap Penjualan.

\section{b. Uji Hipotesis Pengaruh Iklan Terhadap} Penjualan

$$
t=0.361 \sqrt{\frac{79-2}{1-0.361^{2}}}
$$

$$
t=0.361 \sqrt{\frac{77}{1-0.130}}
$$

$$
t=0.361 \sqrt{\frac{77}{0.87}}
$$

$$
t=0.361(9.407)
$$

$$
t=3.395
$$

Berdasarkan hasil perhitungan diatas diperoleh t.hitung $=3.395$ sedangkan t.tabel dengan taraf signifikasi $5 \%$ dan derajat kebebasan $\mathrm{Dk}=\mathrm{n}-2$ atau $79-2=77$, maka $a$ 
$=1.991$, Karna t.hitung lebih besar dari t.tabel yaitu $3.395>1.991$ maka Ho ditolak dan $\mathrm{Ha}$ diterima, artinya terdapat pengaruh antara Iklan terhadap Penjualan.

\section{c. Uji Hipotesis Pengaruh Saluran}

Distribusi dan Iklan Secara Simultan

\section{terhadap Penjualan}

Uji ini digunakan untuk menguji pengaruh dari seluruh variabel independen secara bersama-sama terhadap variabel dependen. Hipotesis dirumuskan sebagai berikut :

$$
\begin{aligned}
& t=r \sqrt{\frac{n-2}{1-r^{2}}} \\
& =0,544 \sqrt{\frac{79-2}{1-(0,544)^{2}}} \\
& =0,544 \sqrt{\frac{77}{1-(0,295)}} \\
& =0,544 \sqrt{\frac{77}{0,705}} \\
& =0,544(10.45) \\
& =5.684
\end{aligned}
$$

Berdasarkan hasil perhitungan diatas diperoleh t.hitung $=5.684$ sedangkan t.tabel dengan taraf kesalahan $5 \%$ dan derajat kebebasan $\mathrm{dk}=\mathrm{n}-2=79-2=77$, maka t.tabel $=1.991$, Karena t.hitung lebih besar dari t.tabel yaitu sebesar (5.684 >1.991), maka Ha diterima dan Ho ditolak, artinya terdapat pengaruh antara saluran distribusi dan iklan terhadap penjualan.

\section{Uji f}

Uji f dilakukan untuk mengetahui signifikan atau tidaknya pengaruh antara saluran distribusi dan iklan terhadap penjualan secara bersama-sama untuk menghitung uji f tersebut dapat menggunakan rumus sebagai berikut:

$$
F h=\frac{r^{2} / k}{\left(1-r^{2}\right) /(n-k-1)}
$$

$$
\begin{aligned}
& F h=\frac{(0.544)^{2} / 2}{\left(1-(0.544)^{2} /(79-2-1)\right.} \\
& F h=\frac{0.147}{0.009} \\
& F h=16.33
\end{aligned}
$$

Berdasarkan hasil perhitungan diatas diperoleh $\mathrm{f}$ hitung $=16.33$ sedangkan $\mathrm{f}$ tabel dengan taraf signifikasi $5 \%$ dan derajat kebebasan $\mathrm{Dk}=\mathrm{n}-2-1$ atau $79-1-2=76$, maka $a=3.12$, Karna f hitung lebih besar dari f tabel yaitu $16.33>3.12$ maka $\mathrm{Ha}$ diterima dan Ho ditolak, artinya terdapat pengaruh yang signifikan antara saluran distribusi dan iklan terhadap penjualan.

\section{KESIMPULAN}

1. Saluran distribusi menurut tanggapan dari pelanggan UKM Berkah Laut Eretan Kulon melalui indikator sekumpulan organisasi yang saling bergantung dalam proses membuat prodak atau jasa yang siap digunakan, serangkaian lembaga dalam menyalurkan produk, dan serangkaian lembaga yang menyalurkan produk dalam status kepemilikan dari 
produsen ke konsumen sebesar $76 \%$ termasuk dalam kategori "baik".

2. Iklan menurut tanggapan dari pelanggan UKM Berkah Laut Eretan Kulon melalui indikator, bentuk komunikasi non personal yang dibiayai oleh sponsor, bagian dari bentuk promosi yang digunakan oleh perusahaan, dan media komunikasi dengan sejumlah biaya yang dilakukan oleh perusahaan atau lembaga yaitu sebesar $81 \%$ termasuk dalam kategori "sangat baik".

3. Penjualan menurut tanggapan dari pelanggan UKM Berkah Laut Eretan Kulon melalui indikator sumber pendapatan untuk menutup biaya, harapan untuk mendapatkan keuntungan dari kegiatan barang atau jasa yaitu sebesar $80 \%$ termasuk dalam kategori "baik".

4. Hasil analisis korelasi pengaruh saluran distribusi terhadap penjualan adalah 0.433 maka korelasi saluran distribusi terhadap penjualan termasuk dalam korelasi sedang. Hasil analisis koefisien determinasinya (KD) adalah sebesar $19 \%$ sisanya berasal dari faktor lain yang tidak diteliti. Hasil hipotesisnya adalah T.hitung $=4.213$ sedangkan T.tabel dengan taraf signifikasi $5 \%$ adalah 1.991 Karna T.hitung lebih besar dari T.tabel 4.213 > 1.991 maka Ho ditolak dan $\mathrm{Ha}$ diterima, artinya terdapat pengaruh antara saluran distribusi terhadap penjualan.
5. Hasil analisis korelasi pengaruh iklan terhadap penjualan adalah 0.361 maka korelasi antara iklan terhadap penjualan tergolong dalam korelasi sedang. Hasil analisis koefisien determinasinya (KD) sebesar $13 \%$ sisanya berasal dari faktor lain yang tidak diteliti. Hasil hipotesisnya adalah T.hitung $=3.395$ sedangkan T.tabel dengan taraf signifikasi $5 \%$ adalah 1.991 Karna T.hitung lebih besar dari T.tabel $3.395>1.991$ maka Ho ditolak dan $\mathrm{Ha}$ diterima, artinya ada pengaruh antara iklan terhadap penjualan.

5. Hasil analisis korelasi pengaruh saluran distribusi dan iklan terhadap penjualan adalah 0.544 maka korelasi saluran distribusi dan iklan terhadap penjualan tergolong dalam korelasi sedang. Hasil analisis koefisien determinasinya adalah $\mathrm{KD}=30 \%$ sisanya berasal dari faktor lain yang tidak diteliti. Hasil hipotesisnya adalah t.hitung $=5.684$ sedangkan t.tabel dengan taraf signifikasi 5\% adalah 1.991 Karna t.hitung lebih besar dari t.tabel $5.684>1.991$ maka Ho ditolak dan Ha diterima. Uji $\mathrm{F}$ diperoleh F.hitung = 16.33 sedangkan F.tabel dengan taraf signifikasi $5 \%$ adalah 3.12 Karna F.hitung lebih besar dari F.tabel 16.33 > 3.12 maka Ho ditolak dan Ha diterima, artinya ada pengaruh yang signifikan antara saluran distribusi dan iklan terhadap penjualan. 


\section{DAFTAR PUSTAKA}

Basu, Swastha. 2012. Manajemen Penjualan Edisi 3. Yogyakarta: BPFEYOGYAKARTA.

Basu, Swastha DH dan Ibnu Sukotjo. 2010. Penghantar Bisnis Modern. Yogyakarta: Liberty

Basu, Swastha dan Irawan. 2008. Manajemen Pemasaran Modern. Yogyakarta: Liberty.

Buchari Alma. 2011. Manajemen Pemasaran dan Pemasaran Jasa. Bandung: Alfabeta

Danang, Sunyoto. 2015. Perilaku Konsumen dan Pemasaran. Yogyakarta: CAPS (Center of Academic Publishing Service).

Fandy Tjiptono. 2008. Strategi Pemasaran. Edisi 4. Yogyakarta: Andi.

Henry, Simamora. 2012. Akuntansi Basis Pengambilan Keputusan Bisnis. Jakarta: Salemba Empat.

Hermawan Kertajaya. 2008. On Marketing Mix. Bandung : Mizan.

Husein, Umar. 2014. Riset Pemasaran \& Perilaku Konsumen. Jakarta. PT Gramedia Pustaka Utama.

Morissan, M.A. 2010. Periklanan Komunikasi Pemasaran Terpadu. Jakarta: Kencana Prenadamedia Grup.

Mulyadi. 2013. Sistem Akuntansi. Jakarta: Salemba Empat.

Philip Kotler dan Gary Amstrong. 2012. Prinsip-prinsip Pemasaran. Jakarta: Erlangga.
Renda Widyatama. 2011. Pengaruh Periklanan. Pustaka book publisher: Yogyakarta.

Sugiyono. 2013. Metode Penelitian BisnisPendekatan Kuantitatif. Kulitatif Dan $R \& D$. Bandung : Alfabeta.

http://jurnalskripsitesis.wordpress.com/2014 107/02/Analisis-pengaruh-saluran-distribusiterhadap-volume-penjualan

http://kumpulanmakalahilmiah.blogspot.co.i d/2011/11/peranan-periklanan-dalammeningkatkan.html? $m=1$

http://kumpulanmakalahilmiah.blogspot.co.i d/2011/11/pengaruh-saluran-distribusidan.html? $m=1$ 